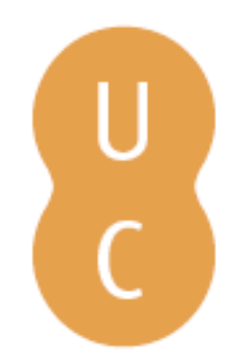

\title{
nombalina
}

\section{Constitutions, contingency and the individual: solon, lycurgus, and the early development of greek political biography}

\author{
Autor(es): $\quad$ Beck, Mark \\ Publicado por: Imprensa da Universidade de Coimbra \\ URL \\ persistente: URI:http://hdl.handle.net/10316.2/32801 \\ DOI: $\quad$ DOI:http://dx.doi.org/10.14195/978-989-26-0236-3_1 \\ Accessed : $\quad$ 26-Apr-2023 12:13:08
}

A navegação consulta e descarregamento dos títulos inseridos nas Bibliotecas Digitais UC Digitalis, UC Pombalina e UC Impactum, pressupõem a aceitação plena e sem reservas dos Termos e Condições de Uso destas Bibliotecas Digitais, disponíveis em https://digitalis.uc.pt/pt-pt/termos.

Conforme exposto nos referidos Termos e Condições de Uso, o descarregamento de títulos de acesso restrito requer uma licença válida de autorização devendo o utilizador aceder ao(s) documento(s) a partir de um endereço de IP da instituição detentora da supramencionada licença.

Ao utilizador é apenas permitido o descarregamento para uso pessoal, pelo que o emprego do(s) título(s) descarregado(s) para outro fim, designadamente comercial, carece de autorização do respetivo autor ou editor da obra.

Na medida em que todas as obras da UC Digitalis se encontram protegidas pelo Código do Direito de Autor e Direitos Conexos e demais legislação aplicável, toda a cópia, parcial ou total, deste documento, nos casos em que é legalmente admitida, deverá conter ou fazer-se acompanhar por este aviso.

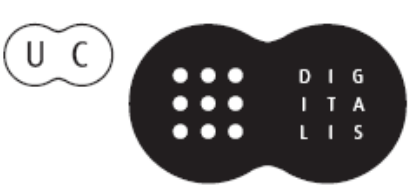


Carmen Soares

Maria do Céu Fialho

María Consuelo Alvarez Morán

Rosa María Iglesias Montiel

Coordenação

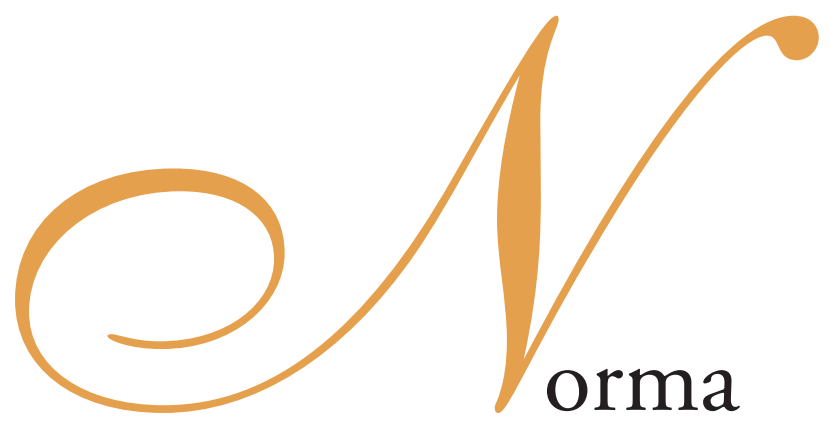

\& Transgressão

II

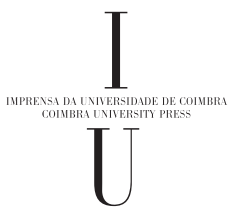


(Página deixada propositadamente em branco) 


\section{CAPÍTULO I}

História da Antiguidade Clássica 
1.1. Política 
Mark Beck

University of South Carolina at Columbia

\title{
CONSTITUTIONS, CONTINGENCY AND THE INDIVIDUAL: SOLON, LYCURGUS, AND THE EARLY Development of Greek Political Biography
}

\begin{abstract}
"From the moment when a subordinate class becomes really independent and dominant, calling into being a new type of State, the need arises concretely of building a new intellectual and moral order, i.e., a new type of society, and hence the need to elaborate the most universal concepts, the most refined and decisive ideological weapons." (Antonio Gramsci, Prison Notebooks)

"I submit that an individual who breaks a law that conscience tells him is unjust, and willingly accepts the penalty by staying in jail to arouse the conscience of the community over its injustice, is in reality expressing the very highest respect for law." (Rev. Dr. Martin Luther King Jr., Letter from a Birmingham City Jail ${ }^{1}$ )
\end{abstract}

The topic of rule breaking in societies is a fascinating one. I automatically associate rules with written laws but there are many unwritten codes that wield great influence in contemporary and ancient societies. Occasionally tensions arise between traditional behaviors which are tacitly accepted and enacted by the multitude and prescriptive laws established without the explicit consent of all members of a society. Social discord becomes the engine of social evolution as factions or groups square off against one another. As Ralf

1 1971: 19. 
Dahrendorf has acutely observed, "social structures as distinct from most other structures are capable of producing within themselves the elements of their supersession and change". ${ }^{2}$ Even individual behavior could threaten and come into conflict with the "rational aims" of the polis. ${ }^{3}$ Sophocles brilliant tragedy the Antigone dramatizes the conflict that arises when a situation of this nature occurs. Kreon's edict forbidding the proper burial of Polyneikes clashes with the unwritten code of supposed divine origin that stipulates the interment of family members by surviving next of kin. The sympathy of the masses is with his sister Antigone, the power of the state, with Kreon. Kreon's position, however, resonates with Athenian law which forbade interment of a traitor on Attic soil. ${ }^{4}$ In flouting his authority Antigone breaks the law, a law which she deems to be illicit because it contravenes the unwritten laws of the gods, an authority that even Kreon must acknowledge, or suffer the consequences, and suffer them he does.

This is western societies' paradigm case of civil disobedience, the repudiation of sanctioned social coercion in the form of laws through verbal or physical acts of resistance, because the laws are regarded as wrong, or unjust, or immoral, or violate deeply held convictions of individuals or groups. Hegel in his work Phenomenology of Spirit perceived the fundamental problem: if these laws of the gods require conscious validation then "their unshakeable, intrinsic being" is called into question. ${ }^{5}$

\footnotetext{
2 1959: viii.

3 See N. White 2002: 124-154, esp. 124.

4 The remains of Phokion, for example, were subjected to this punitive act. Cf. Plutarch's Life of Phokion 37.3-5.

5 See G. Hegel 1977: 261-262: of the gods

“Thus, Sophocles' Antigone acknowledges them as the unwritten and infallible laws
} They are not of yesterday or today, but everlasting, Though where they came from, none of us can tell (456-457).

They are. If I inquire after their origin and confine them to the point whence they arose, then I have transcended them; for now it is I who am the universal, and 
The hero of a Greek tragedy subscribes to one ethical system or behavioral pattern, often very rigidly, as Bernard $\mathrm{Knox}^{6}$ has shown, only to enter into conflict with another. How a society resolves competing claims is a significant determinant of their long-term viability.

Historically Republican Rome was one of the most enduring and successful examples of a society that successfully mediated between such conflicting claims. ${ }^{7}$ Polybius localized the source of Rome's successful expansion in their mixed constitution which was not the work of any one individual, as far as he knew and we know today. ${ }^{8}$ This differed from the Greek paradigm, as he was well aware. Constitutions in the Greek world were tied to notable individuals, renowned lawgivers, such as Solon of Athens and Lycurgus of Sparta, whose achievements were memorialized by their respective populaces and beyond. These men exerted a profound transformative influence on their societies. They supplanted old laws with new ones. They are in this sense rule breakers as well as rule makers. The association of dramatic constitutional change with prominent individuals reflects a unique aspect of Greek social development with discernable repercussions for the development of political biography. ${ }^{9}$ What circumstances, in other words, fostered the assimilation of the life stories of individuals associated with constitutional changes into the oral tradition and collective memory of societies and give rise to what we call political biography? By what means or through what commemorative acts and edifices are the memories of these

they are the conditioned and limited. If they are supposed to be validated by my insight, then I have already denied their unshakeable, intrinsic being, and regard them as something which, for me, is perhaps true, but also is perhaps not true. Ethical disposition consists just in sticking steadfastly to what is right, and abstaining from all attempts to move or shake it, or derive it." (translation by A. V. Miller)

The most extensive analysis of Hegel's views on the individual and the Greek polis is now N. White 2002.

61964.

7 On the Roman constitution see A. Lintott 1999 and F. Millar 2002.

8 See A. Heuss 1995: 29-30, who discusses this with regard to contingency and the individual.

9 A. Dihle 1987 accurately represents the present state of research on this topic. 
individuals kept alive and modified over time as their societies evolve and change?

In what follows I will explore this topic by examining the relationship between the important roles they assumed in their respective communities as lawgivers, and the historiographical and biographical tradition that eventually emanated from their actions. In particular I am interested in establishing the connection between the charismatic individual, in the sense of the term as it is employed by Max Weber, ${ }^{10}$ and the aspect of contingency as it relates to individual activity in the creation of new laws and new ideological frameworks. ${ }^{11} \mathrm{I}$ will also consider the possible role played by collective, social, or cultural memory, as the phenomenon is variously termed, and oral tradition in the development of the biographical tradition surrounding these two men, to the extent that this is ascertainable. For Weber, "the charismatic hero does not deduce his authority from codes and statutes" nor "from traditional custom or feudal vows of faith", rather charismatic authority "flows from personal strength" that is "constantly being proved". ${ }^{12}$ His power springs, according to Weber, from "faithful devotion...born of distress and enthusiasm". ${ }^{13}$ The charismatic hero breaks with the status quo:

Charismatic domination means a rejection of all ties to any external order in favor of the exclusive glorification of the genuine mentality of the prophet and hero. Hence its attitude is revolutionary and transvalues everything; it makes a sovereign break with all traditional or rational norms: 'It is written, but I say unto you. ${ }^{14}$

\footnotetext{
10 See M. Weber 1968.

11 The topic of contingency is briefly broached by K.-J. Hoelkeskamp 2005: 280-293, who addresses it from the perspective of the question of the existence of the law code in early Greek society.

12 M. Weber 1968: 22.

13 M. Weber 1968: 23.

14 M. Weber 1968: 24.
} 
Weber stresses the importance of heroism and intellectual dominance in the perception of charisma and the capacity inherent in charismatic individuals of fostering a legitimate tradition subscribed to by his or her successors:

Genuine charisma ... does not appeal to an enacted or traditional order, nor does it base its claims upon acquired rights. Genuine charisma rests upon personal heroism or personal revelation. Yet precisely this quality of charisma as an extraordinary, supernatural, divine power transforms it, after its routinization, into a suitable source for the legitimate acquisition of sovereign power by the successors of the charismatic hero. ${ }^{15}$

Weber's concept of charisma is widely applicable in ancient Greek literature, but clearly its most vital heuristic association is with biographical literature.

\section{The Development of Greek Biography: Orality, Ideology, Identity, and Collective Memory}

The story of the inception and early development of Greek political biography must necessarily, for lack of concrete evidence, remain a venture in speculative reconstruction. Traditionally the genre's earliest beginnings are sought in works belonging to a different genre. Helene Homeyer regards the biographical Herodotus' sketches of Cyrus (1.107-130.3, 177-188, 201214.5) and Cambyses (3.1-66) in the Histories, as the literary precursors of the genre that antedate Friedrich Leo's and Albrecht Dihle's prime candidate, Plato's Apology of Socrates ${ }^{16}$ Herodotus then, according to Homeyer, is not just the father of history he is also the originator of political biography. ${ }^{17}$ As to the question of whether or not Herodotus had any predecessors,

\footnotetext{
15 M. Weber 1968: 39.

16 1962: 75-85. See F. Leo 1901: 101 and 242, and A. Dihle 1970²: esp. 18 and 34.

17 1962: 81: So ist Herodot nicht nur der Vater der Geschichte, sondern zugleich auch der Schöpfer eines Zweiges der biographischen Darstellungsweise geworden, die bis zu Plutarch reicht.
} 
Homeyer is quite explicit: "There is no indication that biographical representations of historical personalities in Greek prose existed prior to Herodotus." ${ }^{8}$ There may not have been any prose depictions perhaps, but there are nevertheless clear indications that an oral tradition preceded Herodotus and that he drew on this tradition. Homeyer herself acknowledges the oral provenance of some elements of the Cyrus-logos. ${ }^{19}$ Since Homeyer substantial progress has been made in ascertaining the range of Herodotus's debt to this oral tradition. ${ }^{20}$ Undoubtedly this tradition transmitted a significant amount of biographical information concerning prominent individuals. What factors influenced its development?

The early development of Greek biography most likely goes back to an oral tradition that relied on word-of-mouth reports of what influential people did and said --- gossip if you will. ${ }^{21}$ With few exceptions, the Greeks apparently did not have "a class of professional remembrancers". 22 Gossip, as Virginia Hunter points out, "is expressive of the norms, values, and ideology of a given community and of the larger society of which that community is a part". ${ }^{23}$ She goes on to note that gossip is a "mode of oral communication" principally concerned with reputation that "holds up to criticism, ridicule, or abuse those who flout society's or the community's accepted rules". ${ }^{24}$ Gossip in a fundamental way encourages conformity and this outcome may be a positive one in that it helps to protect and preserve a society's highest ideals. ${ }^{25}$ Jan Vansina, in his influential book Oral Tradition

\footnotetext{
18 1962: 82: "Nichts deutet daraufhin, daß es vor Herodot beriets biographische Darstellungen historischer Persönlichkeiten in griechischer Prosa gegeben hat."

19 1962: 77

20 See in particular R. Thomas 1992 and 2001, P. Stadter 1997and 2004, O. Murray 2001, and S. Slings 2002 .

21 On gossip in classical Athens see V. Hunter 1990.

22 O. Murray 2001: 26.

23 1990: 299-300.

24 1990: 300.

25 1990: 300.
} 
as History, calls this hearsay or rumor which he describes as the "fountainhead of most tradition or most written documents". ${ }^{26}$ He furthermore makes the important observation that:

Rumor is the process by which a collective historical consciousness is built. The collective interpretations resulting from massive rumors lead to commonly accepted interpretations of events, nonevents, or sets of events. Hence a tradition based on rumor tells more about the mentality at the time of the happening than about the events themselves. ${ }^{27}$

These interpretations of events become fused into collective memories and "groups of traditions" that in turn are "abraded to anecdotes". ${ }^{28}$ Anecdotes represent the residual remnants of what likely was a daily torrent of transmitted gossip and rumor ( $\varphi \eta n \mu \eta)$. The survival and transmission of these anecdotes and stories about significant individuals and events would be governed by their importance to their respective communities as the communities evolve and develop. From an ideological perspective, the traditions thus formed in the past often serve to justify contemporary conditions or circumstances. ${ }^{29}$ A shared historical tradition helps to establish group consciousness and identity. ${ }^{30}$ The crystallization of these accounts around the figure of a "single culture hero" is a well-known and frequently occurring phenomenon in oral traditions. ${ }^{31}$ Both in oral and literary traditions a certain amount of idealization occurs as these figures come to reflect exemplary and ideal types in their societies. ${ }^{32}$ The individuals so favored in these traditions assume the status of prototypes, as "anecdotes that originally belonged to other persons who were not so idealized were reattributed to

\footnotetext{
26 1985: 6.

27 J. Vansina 1985: 6.

28 J. Vansina 1985: 21.

29 J. Vansina 1985: 103.

$30 \mathrm{~J}$. Vansina 1985: 105.

31 J. Vansina 1985: 22.

32 J. Vansina 1985: 106.
} 
the prototypical character" (Wanderanekdoten). ${ }^{33}$ As Vansina notes, these traditions "adhere to the 'great man' school of history". ${ }^{34}$ Gossip, interesting stories etc. tend to collect around famous people and some of this is transmitted in the form of anecdotes. The credibility of many entertaining, amusing or bizarre anecdotes is often directly contingent on the fame, grandeur, esprit, or known cleverness of the subject. If statements or assertions conveyed in an anecdote are not coincident with the known characteristics of the person in question, its credibility or veracity would then be subject to scrutiny and the skeptical attitude it elicits would serve to impede its further transmission or spread. ${ }^{35}$

This public pastime of gossip and the ensuing formation and transmission of anecdotes undoubtedly played an instrumental role in the development of biographical literature at that point in time when the textual fixation of this oral tradition occurred. Arnaldo Momigliano suggests, for example, that an anecdotal tradition arose associated with the Seven Wise Men. ${ }^{36}$ In fact, he even goes so far as to say that: "The existence of fifth-century biography [sic] of poets and Wise Men is conjectural but, I should say, altogether likely".37 What, however, determined which stories or anecdotes would survive and continue to be transmitted as part of a society' or community's legacy and lore to eventually become the rudiments of someone's life story? How are we to envision this process taking place in pre-literate or proto-literate societies?

Recently Jan Assmann has investigated the question of how ancient cultures remember the past. ${ }^{38}$ In synthesizing the research of Maurice

33 J. Vansina 1985: 106.

34 J. Vansina 1985: 108.

35 The influence of oral tradition and Roman historiography had been well-discussed by J. Ungern-Sternberg 1988: 237-265 and D. Timpe 1996: 277-300.

36 19932: 37f., 53 and M. Beck 2005.

37 19932: 28.

381997 and 2000. For a general summary of the history of research on collective or social memory see the excellent article by J. Olick and J. Robbins 1998: 105-140. 
Halbwachs ${ }^{39}$ on collective memory and contemporary research on the oral tradition, ${ }^{40}$ Assmann discerns a difference between relatively unstructured and disorganized memory of recent past events (kommunikatives Gedächtnis) and memory of events which occurred in the distant past which, through a process of formalization, were integrated into the society's cultural code (kulturelles Gedächtnis). ${ }^{41}$ Orally transmitted knowledge of the past, according to Assmann, is thus sustained by virtue of its cultural significance. The meaning and import an event has culturally is thus the determinant of its form and survival in oral histories, commemorative ceremonies, value systems, and ideological constructs.

Building on the fundamental work of Max Weber, attention has lately been focused on the hermeneutic importance of semiotic significance (Sinn) in unlocking the ideological complexity of ancient cultures. ${ }^{42}$ The introduction to the volume entitled Sinn (in) der Antike: Orientierungssysteme, Leitbilder und Wertkonzepte im Altertum contains a lapidary assessment of the interpretive category of meaning:

The category of semiotic significance is suitable for designating the fundamental nature of culture for human life in general and simultaneously its uniqueness as a dimension or defining characteristic of this life in contrast to other lives. Meaning is universal, the intellectual breath, so to speak, of human life. Semiotic significance is the embodiment of the interpretation of one's self and world, i.e. it appears when people have to understand or interpret themselves or their world in order to be able to live. 43

\footnotetext{
391997 and 2000 .

40 Especially that of J. Fentress and Ch. Wickham 1992.

41 For a fine discussion of J. Assmann's work in relation to early Greek historiography see N. Luraghi 2001: 14-15.

42 K.-J. Hölkeskamp, J. Rüsen, E. Stein- Hölkeskamp, and H. Grütter (eds.) 2003.

${ }^{43}$ K.-J. Hölkeskamp, J. Rüsen, E. Stein- Hölkeskamp, and H. Grütter (eds.) 2003: 2 (my translation): "Die Sinnkategorie ist geeignet, die Grundsätzlichkeit der Kultur für das menschliche Leben insgesamt und zugleich ihre Besonderheit al seine Dimension oder Bestimmtheit dieses Lebens neben anderen zu bezeichnen. Sinn ist Inbegriff von Selbst- und Weltdeutung, d.h. er
} 
From a sociological viewpoint semiotic significance (Sinn) is generally comprehended as being a conceptual framework (Sinnkonzept) that helps to orient us culturally by facilitating thought, activity, and identity. ${ }^{44}$ The closeness of this activity to more developed definitions of the meaning of ideology is significant. Change ensues in a society's conceptual framework when situations arise that challenge its norms and value systems. In such cases the incompatibility of long held belief systems with current events and affairs initiates a developmental process in which new and different normative belief systems supplant older obsolete ones.

It is easy to see how the concept of Sinn or meaning, with its capacity to define and orient human life is closely associated with Assmann's observations about the selective survival of memories of events vis-à-vis others in the process of their integration into a society's cultural code which he terms cultural memory. Anecdotal information about individuals would thus be assimilated into cultural memory if the actions or statements of the individual are in some way ideologically meaningful in establishing or reaffirming the identity and value system of a society. The sociologists Olick and Robbins have expressed this interrelationship between cultural or social memory, tradition, and frameworks of meaning well:

The view that all meaning frameworks have histories and that explicitlypastoriented meaning frameworks are prominent modes of legitimation and explanation leads to increased interest in social memory because it raises questions about the transmission, preservation, and alteration of these frameworks over time. ${ }^{45}$

tritt immer dann auf, wenn Menschen sich selbst und ibre Welt verstehen oder deuten müssen, um leben zu können."

${ }^{44}$ K.-J. Hölkeskamp, J. Rüsen, E. Stein- Hölkeskamp , and H. Grütter (eds.) 2003: 3, citing the definition arrived at by the study group "Sinnkonzepte als lebens und handlungsleitende Orientierungssysteme": "Ein Sinnkonzept läßt sich folgendermaßen definieren: Es ist ein plausibler und verläßlich beglaubigter reflektierter bedeutungszusammenhang der Erfahrungs- und Lebenswelt und dient dazu, die Welt zu erklären, Orientierungen vorzugeben, Identität zu bilden und Handeln zweckhaft zu leiten."

45 1998: 108. 
The instrumentalization of historical narratives centered around the life of an individual can therefore serve to legitimize or challenge the dominant political landscape of the author's present. The meaningfulness of the historical moment in its contemporary relevance is at issue here. Or, to put it another way, "history's epistemological claim is devalued in favor of memory's meaningfulness". ${ }^{46}$

If we return to Herodotus we can discern some of these principles operative in his Histories. In particular the depiction of Solon's encounter with Croesus is very important and sets the stage for other encounters between Greeks and Barbarians. ${ }^{47}$ This encounter has unfortunately been called a "short story" by Vivienne Gray, along with the narratives of Gyges and Candaules, Arion's travails, Polycrates, Peisistratus, Hermotimus, etc. ${ }^{48}$ I say "unfortunately" because for me the term "short story" conjures up the realm of fiction and I am certain that is not what Herodotus with his reference to bistoriê intends for us to understand. Fiction does not necessarily imply research, rather it requires imagination. A recent definition of "short story" in a standard handbook reads as follows: "A short story is a relatively brief fictional narrative in prose." ${ }^{49}$ An anecdote, however, purports to be a nonfictional account, as a recent definition by E. Rohmer indicates:

Anecdote refers to a brief, often anonymous account of an historical event of small consequence, but great significance, which concludes with a non-verbal (sachlichen) or verbal point. It achieves its effect especially through the 'union of representation' and 'factuality' of the event 'as well as through 'the attitude of reflection' in its narration. ${ }^{50}$

46 J. Olick and J. Robbins 1998: 110.

47 Cf. D. Asheri 2007: 97 ad loc.: "The dialogue between Croesus and Solon on human happiness is one of the most famous passages of book I, a focal point in the whole Croesus logos and Herodotus' work at large, one of the most important sources for Herodotus' ethical, religious, historical, and philosophical views."

48 2002: 291-317.

49 C. Holman and H. Harmon 1986: 469.

50 E. Rohmer 1992: 566. He is quoting J. Hein, "Die literarische Anekdote," Universitas 37 (1982) 641. Hein, in turn is quoting H. P. Neureuter, "Zur Theorie der Anekdote," Jabrbuch der freien deutschen Hochstifts (1973) 458-480. This is my translation; the original reads: "Als A. 
The reference to historicity serves to delimit anecdote from fable, fairy tale, short story, or other "fictional" short narratives. Novalis (1772-1801) recognized the association of anecdote with history:

History is a large anecdote. An anecdote is an historical element, an historical molecule or epigram. A history in anecdotes - Voltaire produced something like this - is a very interesting work of art. History, in its usual form, is a series of anecdotes which have been fused together, or flow together to form a continuum. ${ }^{51}$

The significance of a person's notoriety is a cardinal feature of anecdotes. This aspect of anecdotes which serves to distinguish them from other short forms has been observed by numerous other researchers, ${ }^{52}$ and is in no small measure ascribable to the anecdote's oral origins.

\section{Solon}

The encounter between Solon and Croesus certainly possesses representative significance, as well as at least reputed historicity, and it also exhibits "the attitude of reflection" in its broad ideological ramifications. ${ }^{53}$ It speaks to the meaning of human happiness, while also symbolizing "the confrontation between wisdom and arrogance, moderation and

bezeichnet man eine kurze, oft anonyme Erzäblung eines historischen Geschehens von geringer Wirkung, aber großer Signifikanz, die mit einer sachlichen oder sprachlichen Pointe endet. Sie wirkt insbesondere durch die Verbindung von 'Repräsentaz' und 'Faktizität' des Geschehens 'sowie durch die 'Haltung der 'Nachdenklichkeit' im Erzäblen."

${ }^{51}$ Novalis (Friedrich Leopold Freiherr von Hardenberg), "Die Kunst des Anekdotisierens," Fragmente, chapter: "Die poetische Welt," (ed. by Ernst Kamnitzer) Dresden (1929) 613-616, cited by Heinz Grothe Anekdote, Sammlung Metzler vol. 101, Stuttgart (1984²) 12. My translation: "Geschichte ist ein große Anekdote. Eine Anekdote ist ein historisches Element, ein historisches Molekül oder Epigramm. Eine Geschichte in Anekdoten- etwas Ähnliches hat Voltaire geliefertist ein hochst interessantes Kunstwerk. Die Geschichte in gewöhnlicher Form ist eine zusammengeschweißte, oder ineinander zu einem Kontinuo geflossenen Reihe von Anekdoten."

52 Lange apud H. Grothe 1984²: 10, Behl apud H. Grothe 1984²: 14, and Röhrich apud H. Grothe 19842: 56.

53 On the anecdote's historicity see D. Asheri 2007: 99 ad loc. 
excessiveness, ${ }^{54}$ civic virtue and despotic self-indulgence. Solon speaks the truth to a powerful monarch, despite knowing that such candor could cost him dearly. ${ }^{55}$ He illustrates his responses with examples. The life of Tellus, the unknown Athenian, illustrates an ideal of a well-lived life crowned with a noble death in battle, and Solon claims that only after the finality of death can a statement be made about a person's happiness (olbios). It has gone unnoticed that this is the first biographical sketch in Greek prose literature, but not the first one in Greek literature. That honor belongs to Homer who in bk. 9 of the Iliad has Phoenix relate to Achilles the life of Meleager (Il. 9.528-599). 56 This follows Pheonix's autobiographical account. Both are apotreptic, both present negative examples designed to dissuade Achilles from maintaining his hard line approach towards Agamemnon. The example of Tellus by contrast is wholly positive of course. The anonymity of Tellus could also indicate that he is not a member of the elite. He is not introduced with a patronymic reference, e.g son of... He is a good Athenian, a father of sons, who died doing his duty for his city.

The Solon-Croesus anecdote represents an important aspect of Greek identity that had great contemporary relevance in Herodotus' own day. As Paul Cartledge and others have noted, the Greeks thought in terms opposites: man vs. woman, free vs. slave, Greek vs. Barbarian, etc. These categories are explored in a series of encounters in the Histories. The most important contrast is arguably the one between Greek and Barbarian, however, to which slave vs. freeborn Greek is a subordinate element. Especially in the encounters between Xerxes and the exiled Spartan Demaratus we are witness to the ideological divide separating Greek from barbarian, a meeting that foreshadows the outcome of the battles of Thermopylae, Salamis, and Plataea. The unknown Athenian Tellus symbolizes the Greek commitment to the

\footnotetext{
${ }^{54}$ D. Asheri 2007: 98, ad loc.

55 See P. Cartledge and E. Greenwood 2002: 351, who cite E. Saïd.

56 Noted by P. Stadter 2007: 528.
} 
laws and customs (nomoi) of the community in the same way that the Spartans who chose to fight to the death with their king Leonidas, were obedient to the laws and ideals of Sparta. In contrast, throughout the Histories, Herodotus stresses the slave-like and subservient status of the Persian subjects. They are whipped into battle. Slight transgressions are cruelly punished. Hard physical labor is expected and tolerated, or extracted unwillingly. This cardinal antithesis was of great contemporary significance at the time of the writing of the Histories. In the wake of the Persian Wars, Athens had managed to establish her hegemony over other Greek cities through the Delian league. This imperialistic expansion of Athenian hegemony coincided with a vigorous rebuilding and beautification program of the city itself orchestrated by Pericles in concert with his chief architect Phidias. The grandeur and munificence of the edifices erected on the acropolis must have struck the Athenians themselves and other Greek visitors as being spectacular to the point of approaching oriental opulence. To achieve this, the Athenians had virtually enslaved other Greek states who were compelled to pay tribute or supply ships and crews, or suffer the consequences. Athens removal of the league treasury from Delos to Athens, and the improper use of the funds for its own self-beautification project only served to reinforce the impression of despotic dominance. Sophocles, the close friend of Pericles, and most likely of Herodotus too, ${ }^{57}$ was appointed overall treasurer of this fund (Hellanotamias).

Herodotus was himself present in Athens in the latter part of the $5^{\text {th }}$ century and would have witnessed these changes. John Moles, Sara Forsdyke, and Ryan Balot have suggested that Herodotus in the Histories, in criticizing barbarian despotism, is really simultaneously critiquing Athenian imperialism. ${ }^{58}$ This subjugation or enslavement of other Greeks by a Greek city was

\footnotetext{
57 Stephanie West (1999: 109-135) presents and evaluates the evidence for the friendship between the two men.

58 J. Moles 2001: 33-52, S. Forsdyke 2006: 224-241, esp. 230, R. Balot 2006:156-159.
} 
diametrically opposed to Solon's liberation of enslaved Greeks from debt bondage (seisachtheia). The fragments of his poems reflect this activity and, as David Asheri in his commentary notes, Herodotus may have used this material. He shows an awareness of Solon's legislative activity and its relationship to Solon's travels abroad (see Her. 2.177.2). ${ }^{59}$ The encounter with Croesus thus has profound contemporary significance. The figure of Solon is thus warning Herodotus' Athenian contemporaries at the same time he is warning Croesus about the uncertainty of the future and the true nature of virtuous conduct and happiness. Solon's fortuitous presence during a period characterized by stasis is an instance of contingency that saved the city. His appearance in Herodotus' anecdote was designed to have the same effect at a time when the Greek world as a whole was rocked by staseis (Thuc.). ${ }^{60}$

Another circumstance that contributed to the firm establishment of Solon's presence in oral tradition is public performance. There are two primary modes of performance: poetry and oratory. On the authority of Anaximenes, cited by Diogenes Laertius (1.40), we know that all of the Seven Sages composed poetry. Richard P. Martin has recently explored the role of poetry and performance in the political activity of the Seven Sages. ${ }^{61}$ Martin observes that, "the functions of the wise men as poets and as actors come together in their production of memorable sayings." ${ }^{2}$ "Such proverbs", he notes, "can function as kernels of full-blown narratives." ${ }^{3}$ This is especially true if the performance is associated with notable or exotic details that would spontaneously induce recollection, retelling and, foster oral transmission. The retention of such memorable statements and actions by audiences in the late archaic period would thus be supported by multiple modalities.

\footnotetext{
59 See also Diodorus Siculus 1.96.2 and 1.98.1 and V. Fadinger 1996: 179-218, esp. 181-183.

60 See H.-J. Gehrke 1985.

61 R. Martin 1998: 113.

62 R. Martin 1998: 118.

63 R. Martin 1998: 118.
} 
With the increasingly widespread use of writing their textual fixation would be ensured. We do have evidence of their inscriptional commemoration at Delphi, a Panhellenic location strongly associated with the Seven Wise men. ${ }^{64}$ These collected maxims, termed the "Commandments of the Wise Men," were originally inscribed on a Stele dedicated at Delphi. Solon's laws were likely committed to writing immediately in ca. 594 BCE. ${ }^{65}$ In the case of Solon we have poems that serve as explanatory commentary on his lawgiver role. Only from Solon do we possess substantial poems and fragments that have been transmitted to us primarily in the Life of Solon by Plutarch and in Aristotle's Athenian Constitution. ${ }^{66}$ P. J. Rhodes, in his extensive study of the Athenian Constitution, explains the considerable overlap in their accounts of Solon and the citations from his poems as indicative of a common source of most likely $5^{\text {th }}$ century provenance. ${ }^{67}$ Solon expressed his views on political and morality, as well as his general thoughts on life in his poems. He was aware of the didactic efficacy of poetry as opposed to prose as a conveyor of philosophical maxims and its utility in the political realm (cf. fr. 2 and Plut. Sol. 3.4).

This is not the place to enter into a detailed discussion of the social and intellectual role of poetry and its practitioners in the archaic Greek world. ${ }^{68}$ What seems to be clear is that Solon was the first champion of the people (Ath. Pol. 2.2; 28.2). He attempted to communicate with them in public settings and used on occasion poetry for that purpose. He also appears to have put on dramatic performances to capture their attention and marshal their support for important issues. Plutarch, our best later source, recounts that he simulated madness, donned a herald's cap, and leapt upon the

\footnotetext{
64 N. Oikonomides 1980 and 1987.

65 See W. Harris 1989: 50 n. 24.

66 For a recent comprehensive assessment of our sources on Solon see D. Leão 2001.

67 1984: 20.

68 See for example B. Gentili 1988, esp. chapter ix. T. Whitmarsh (2004) has an interesting chapter (4) on the performance of poetry at symposia, with a fairly recent bibliography. He does not delve into Solon's political use of poetry and performance specifically, however.
} 
speaker's platform where he delivered a 100 verse long poem to encourage the Athenians, who were wavering, to seize the island of Salamis from Megara (Plut. Sol. 8.1-2). By virtue of this "performance" Solon was able to induce the Athenians' to break the law and wage war with himself in command (Plut. Sol. 8.3). The instance of rule-breaking associated with a performative act of an evidently charismatic individual should be noted here. The fact that they placed Solon in command indicates that they saw through his feigned insanity and trusted his leadership. ${ }^{69}$ The term ethnologists apply to this type of behavior is "play". Dwight Conquergood provides an excellent description of the sociological significance of this type of activity:

This term [sc. play] is linked to improvisation, innovation, experimentation, frame, reflection, agitation, irony, parody, jest, clowning, and carnival. As soon as a world has been made, lines drawn, categories defined, hierarchies erected, then the trickster, the archetypal performer, moves in to breach norms, violate taboos, turn everything upside down. By playing with social order, unsettling certainties, the trickster intensifies awareness of the vulnerability of our institutions. The trickster's playful impulse promotes a radical self-questioning critique that yields a deeper self-knowledge, the first step towards transformation. ${ }^{70}$

Solon's activities in the public sphere evoke comparison with the antics of the trickster figure qua culture hero of Greek mythology. ${ }^{71} \mathrm{He}$ uses deception, but in the service of the greater good. Richard Baumann explains how performance influences social control:

It is part of the essence of performance that it offers to the participants a special enhancement of experience, bringing with it a heightened intensity of communicative interaction which binds the audience to the

69 Cf. Demosthenes De falsa legatione 19, Diogenes Laertius 1.46, and also Plutarch comp. Sol. et Pub. 4.2.

70 2007: 39.

71 See On the Trickster figure and culture hero in Greek mythology see recently W. Hansen 2004: 141-143 and 309-314. The most important divine trickster figure/culture hero in Greek mythology is Prometheus. 
performer in a way that is specific to performance as a mode of communication. Through this performance, the performer elicits the participative attention and energy of his audience, and to the extent that they value his performance, they will allow themselves to be caught up in it. When this happens the performer gains a measure of prestige and control over his audience--prestige because of the demonstrated competence he has displayed, control because the determination of the flow of the interaction is in his hands. ${ }^{72}$

The authority and respect Solon wields leads to his election as archon after Philombrotos and his appointment as mediator (diallaktes) and lawgiver (nomothetes) (Plut. Sol. 14.4). One of his first acts is the repeal of the laws of Draco (Plut. Sol. 17.1).

Lastly I would like to touch on the physical memorials Solon left, around which memories pertaining to his life and activities could generate and collect. I am referring to the wooden kurbeis upon which were inscribed his laws (Plut. Sol. 25.1-2) and the temple of Enalios he erected to commemorate the Athenian victory under his generalship over Megara for the possession of Salamis (Plut. Sol. 9.7). Both, as Plutarch informs us, were still extant in his own day. The importance of such physical objects for the transmission and sustainment of collective memory is well-known. Salamis become the salvation of the Athenians during the Second Persian War when Xerxes captured Athens (480 BCE). Solon's service to his city had lasting ramifications. Aristotle's Constitution of the Athenians (9.2) reports mistakenly that it was Solon's intention to introduce democracy. This clearly points to the prevalent notion that Solon (not Cleisthenes) was the founder of the Athenian democracy. He had become, as it were, a founding father in the Athenian pantheon of local heroes.

72 2007: 35-36. 


\section{Lycurgus}

Lycurgus is a much more difficult historical figure to pin down, if he existed at all. It may therefore seem odd to include him in a discussion of biography, yet for our ancient authorities he did exist. Plutarch, for example, in the proem to his Life of Lycurgus notes the general disagreement in his sources regarding Lycurgus' origins but nowhere disputes his existence (Plut. Lyc. 1-2). In a recent article the ancient historian Lukas Thommen has established that the person of Lycurgus is absent in our earliest sources, e.g. Alcman and Tyrtaeus (esp. his $7^{\text {th }}$ century account of the 'Great Rhetra'), and that the tradition surrounding his lawgiving activity arose later. ${ }^{73}$ Herodotus (1.65-66) is our earliest historical source for Lycurgus. As in the case of Solon performance is allied to political activity, at least in Plutarch's works. One notable demonstration involves an ancient breeding experiment and occurs in the collection of Spartan Sayings (Mor. 225E-F) and in the treatise of disputed authenticity On the Education of Children (Mor. 3A-B). ${ }^{74}$ Lycurgus, so we are informed, reared two puppies from the same litter, one was taught to hunt, the other led a soft life indoors. When the two dogs were then later exposed to a hare only one of them was able to pursue and kill it. The anecdote ends with the direct quotation of Lycurgus explaining the significance of what they have witnessed to the onlookers: 'Citizens, do you see how, although these dogs belong to the same family, their upbringing for life has made turn out very different indeed from each other? Do you see, too, how education is more effective than birth for producing noble behavior?'75 The demonstration obviously has important ramifications for Lycurgus' alleged reforms, especially rather brutal customs such as the krypteia.

\footnotetext{
73 2000: 45, 50-52.

74 See the discussion in M. Beck 2005: 57-59.

75 Translation by R. J. A. Talbert 1988: 147-148.
} 
That these reforms were not undertaken without controversy is clear from another example also cited by Plutarch. We are informed both in the Life of Lycurgus (11.1-8) and in the collection of Spartan Sayings (Mor. 227A-B) that Lycurgus introduction of communal dining, the sussitia, elicited public outrage. ${ }^{76}$ We are informed It is notable for displaying Lycurgus' measured and thoughtful response Forced by an angry mob of fellow citizens to flee for his life, Lycurgus is assaulted by one Alkander who succeeds in overtaking him and knocks out one of Lycurgus' eyes with his staff. Alkander's punishment for this deed is unique and unusual. He is placed in Lycurgus' personal custody where his intimate association with the Spartan lawgiver is meant to encourage the positive development of his character. Ultimately, we are informed, Lycurgus erected a sanctuary in honor of Athena with the epithet of Optilletis to commemorate his loss, while simultaneously no doubt broadcasting the significance of his response. This commemorative foundation fosters of course the repeated retelling of this act, i.e. collective memory. The institution of sussitia prevailed and its institution was thereby attributed to Lycurgus.

In conclusion I have attempted to show that the phenomenon of rulebreaking in ancient Greece is symptomatic of social discord and is associated with influential individuals who were the right people in the right place at the right time---prime examples of the "aleatory element" 77 , i.e. contingency, in social change and reform instituted by individuals. Solon is the paradigmatic example and really the first historical persona to emerge in the $7^{\text {th }}$ and $6^{\text {th }}$ centuries from the mists of myth and legend, and assume tangible form as a living and breathing individual whose existence is undisputed. The farreaching social ramifications of his role as lawgiver explain only in part the development of the hardy and vital tradition that survived the centuries in

76 As I have presented my interpretation of this anecdote at length elsewhere (M. Beck 1999), I will confine myself to a few observations pertinent to the subject at hand.

77 The term was coined by the American sociologist William Graham Sumner who used it to convey the importance of chance in human affairs in his book Folkways, published in 1906. For an appreciation of the role of the aleatory element in biography see J. Manis 1992: 390399, who cites Sumner. 
a semiliterate society. Both Solon and Lycurgus were certainly known for their words and deeds but they were also looked upon as the saviors of their respective societies. The meaning and importance of their undertakings on behalf of their respective poleis conduced to the dissemination of narrative traditions that ultimately found resolution in biographical form. The physical commemoration of their actions in monuments and ritual celebrations further served to solidify their presence in social memory and the textual tradition. The development of a biographical tradition surrounding these two individuals certainly has much to do with the public performances that they put on in support of controversial legislative and military measures. Performance played a key role in enabling them to gain a measure of prestige within and control over their populaces. They proved capable of initiating changes and of transforming their societies, often in subtle ways. They were charismatic individuals, in the Weberian sense of the term, who came to be imbued with a special status in their own communities and beyond. They were great rule breakers as well as rule makers.

\section{Bibliography}

D. Asheri (2007) A Commentary on Herodotus, vol. I, Oxford.

J. Assmann (1997) Das kulturelle Gedächtnis: Sachrift, Erinnerung und politische Identität in frühen Hochkulturen, Munich.

- (2000) Religion und kulturelles Gedächtnis, Munich.

R. K. Balot (2006) Greek Political Thought, Malden, Oxford, Victoria: Blackwell Publishing.

R. Bauman (2007) "The Emergent Quality of Performance", in L. Monaghan and J. E. Goodman (eds.), A Cultural Approach to Interpersonal Communication: Essential Readings, Malden, Oxford, Victoria: BlackwellPublishing.

M. Beck (2005) "The Presentation of Ideology and the Use of Subliterary Forms in

Plutarch's Works", in Historical and Biographical Values of Plutarch'sWorks. Studies devoted to Professor Philip A. Stadter by the International Plutarch Society, edited by Aurelio Pérez Jiménez and Frances Titchener Jimenez, Madrid-Málaga: 51-68.

P. Cartledge and E. Greenwood, "Herodotus as Critic: Truth, Fiction, Polarity", in Brill's Companion to Herodotus, ed. by E. J. Bakker, I. J. F. de Jong, and H. van Wees, Leiden, Boston, Cologne: Brill: $351-371$.

D. Conquergood (2007) "Poetics, Play, Process, and Power: The Performative Turn in Anthropology", in L. Monaghan and J. E. Goodman (eds.), A Cultural Approach to Interpersonal Communication: Essential Readings, Malden, Oxford, Victoria: Blackwell Publishing. 
R. Dahrendorf (1959) Class and Class Conflict in Industrial Society, Stanford.

A. Dihle $\left(1970^{2}\right)$ Studien zur griechischen Biographie. Göttingen.

-, Die Entstehung der historischen Biograpabie, Sitzungsberichte der Heidelberger Akademie der Wissenschaften, Philosophisch-historische Klasse (Heidelberg 1987).

V. Fadinger (1996) "Solons Eunomia-Lehre und die Gerechtigkeitsidee der

altorientalischen Schöpfungsherrschaft”, in H.-J. Gehrke and A. Möller (eds.), Vergangenheit und Lebenswelt: Soziale Kommunikation,Traditionsbildung und historisches Bewußtsein, Tübingen: 179-218.

M. Fauser (1994) "Chrie.” Historisches Wörterbuch der Rhetorik. Vol. 2. Ed. G. Ueding. Tübingen: 190-197.

J. Fentress and Ch. Wickham (1992), Social Memory, Oxford: Blackwell.

S. Forsdyke (2006) "Herodotus, political theory and political thought", in C. Dewald and J. Marincola (eds.), The Cambridge Companion to Herodotus, Cambridge: 224-241.

H.-J. (Gehrke (1985) Stasis. Untersuchungen zu den inneren Kriegen in den griechen Staaten des 5. und 4. Jh. v. Chr., Munich 1985.

B. Gentili (1988) Poetry and its Public in ancient Greece: From Homer to the Fifth Century, translated, with an introduction, by A. Thomas Cole, Baltimore and London.

V. Gray (2002) "Short Stories in Herodotus' Histories", in Brill's Companion to Herodotus, ed. by E. J. Bakker, I. J. F. de Jong, and H. van Wees, Leiden, Boston, Cologne: Brill: 291-317.

H. Grothe (1984²) "Anekdote," Sammlung Metzler vol. 101. Stuttgart.

M. Halbwachs (1992) On Collective Memory, edited, translated and with an introduction by L. A. Coser, Chicago.

W. Hansen (2004) Classical Mythology: A Guide to the Mythical World of the Greeks and Romans, Oxford.

G. W. F. Hegel (1977) Phenomenology of Spirit, translated by A. V. Miller with analysis of the text and forward by J. N. Findlay, Oxford.

A. Heuss (1995), "Kontingenz in der Geschichte", in U. Walter (Ed.), Gesammelte Schriften in drei Bänden, vol. 3, Stuttgart: 2128-2157.

K.-J. Hölkeskamp, J. Rüsen, E. Stein- Hölkeskamp, and H. T. Grütter (2003) Sinn (in) der Antike: Orientierungssysteme, Leitbilder und Wertkonzepte im Altertum, Mainz on the Rhine.

K.-J. Hölkeskamp (2005) "What's in a Code? Solon's Laws between Complexity, Compilation, and Contingency", in Hermes, Vol. 133, No. 3: 280-293.

C. H. Holman and H. Harmon (1986), A Handbook to Literature $5^{\text {th }}$ ed., New York, London.

H. Hommeyer (1962) "Zu den Anfängen der griechischen Biographie”,in Philologus 106: 75-85.

V. Hunter (1990) "Gossip and the Politics of Reputation in Classical Athens", in Phoenix, vol. 44/4: 299-325.

E. Kent (1971), Revolution and the Rule of Law, edited by Edward Kent, Englewood Cliffs.

M. L. King Jr. (1971), "Letter from a Birmingham City Jail", in E. Kent (ed.) Revolution and the Rule of Law (Englewood Cliffs 1971) 12-29.

Th. Klauser and P. Labriolle (1950) "Apophthegma", in Reallexikon für Antike und Christentum. Stuttgart: $545-550$.

B. M. W. Knox (1964) The Heroic Temper: Studies in Sophoclean Tragedy, Sather Classical Lectures, vol. 35 (Berkeley, Los Angeles, London.

D. F. Leão (2001) Sólon: Ética e Política, Lisbon. 
F. Leo (1901) Die griechische-römische Biographie nach ihrer litterarischen Form, Leipzig.

A. Lintott (1999) The Constitution of the Roman Republic, Oxford.

N. Luraghi (Ed.) (2001) The Historian's Craft in the Age of Herodotus, Oxford.

J. G. Manis (1992) "The Aleatory Element in Biography", in Biography, vol. 15, No. 4: 390-399.

R. P. Martin (1998) "The Seven Sages as Performers of Wisdom." Cultural Poetics in Archaic Greece: Cult, Performance, Politics. Ed. C. Dougherty and L.Kurke, Oxford: Oxford University Press.

F . Millar (2002) The Roman Republic in Political Thought, The Menahem Stern Jerusalem Lectures, Hanover, London.

J. Moles (2002) "Herodotus and Athens", in E. J. Bakker, I. F. de Jong, and H. van Wees (eds.), Brill's Companion to Herodotus, Leiden, Boston, Cologne: 33-52.

A. Momigliano (19932) The Development of Greek Biography. Cambridge, Mass.: Harvard University Press.

L. Monaghan and J. E. Goodman (eds.) (2007), A Cultural Approach to Interpersonal Communication: Essential Readings, Malden, Oxford, Victoria: Blackwell Publishing.

O. Murray (2001) "Herodotus and Oral History", in N. Luaghi (ed.), The Historian's Craft in the Age of Herodotus, Oxford: 16-44.

H. P. Neureuter (1973) "Zur Theorie der Anekdote", in Jabrbuch des freien deutschen Hochstifts: 458-480.

A. N. Oikonomides (1980) 'The Lost Delphic Inscription with the Commandments of the Seven and P. Univ. Athen. 2782', ZPE 37: 179-183.

- (1987) "Records of the 'Commandments of the Seven Wise Men' in the $3^{\text {rd }}$ c. B. C.", in Classical Bulletin 63: 67-76.

J. K. Olick and J. Robbins (1998) "Social Memory Studies: from "Collective Memory" to the Historical Sociology of Mnemonic Practices", in Annu. Rev. Sociol. 1998. 24:105-140.

Polybius (1979) The Rise of the Roman Empire, translated by Ian Scott-Kilvert, selected with an introduction by F. W. Walbank, Harmondsworth: Penguin Books,

P. J. Rhodes (1984) Aristotle: The Athenian Constitution, translated with an introduction and notes by P. J. Rhodes, Harmondsworth: Penguin Books.

F. H. Robling and C. Strosetzki. (1992) "Apophthegma", in G. Ueding (Ed.) Historisches Wörterbuch der Rhetorik, vol. 1: A-Bib Tübingen: 823-825.

E. Rohmer (1992) "Anekdote" in G. Ueding (Ed.) Historisches Wörterbuch der Rhetorik. vol. 1: A-Bib, Tübingen: 566-579.

R. Schäfer (1982) Die Anekdote: Theorie-Analyse-Didaktik, Munich.

S. R. Slings (2002) "Oral Strategies in the Language of Herodotus", in E. J. Bakker, I. F. de Jong, and H. van Wees (Eds.), Brill's Companion to Herodotus, Leiden, Boston, Cologne: 53-77.

P. Stadter (1997) "Herodotus and the North Carolina Oral Narrative Tradition", in Histos 1: 1-23.

- (2004) "From the Mythical to the Historical Paradigm: The Transformation of Myth in Herodotus", in J. M. . Morón, F. J. G. Ponce and G. C Andreotti (Eds.) Historia y Mito: El Pasado Legendario Como Fuente de Autoridad, Málaga: 31-46.

- (2007) "Biography and History", in J. Marincola (Ed.), A Companion to Greek and Roman Historiography, vol. 2, Malden, Oxford, Victoria: Blackwell Publishing: 528-540.

R. J. A. Talbert (1988) Plutarch on Sparta, Harmondsworth: Penguin Books.

R. Thomas (1992) Literacy and Orality in Ancient Greece, Cambridge.

- (2001) "Herodotus' Histories and the Floating Gap", in N. Luaghi (ed.), The Historian's Craft in the Age of Herodotus, Oxford: 198-210. 
D. Timpe (1996) "Memoria und Geschichtsschreibung bei den Römern", in H.-J. Gehrke and A. Möller, (Eds.), Vergangenheit und Lebenswelt: Soziale Kommunikation, Tübingen: $277-$ 300 .

J. von Ungern-Sternberg (1988) "Überlegungen zur frühen römischen Überlieferung im Lichte der Oral-Tradition-Forschung”, in J. von Ungern-Sternberg and H. Reinau (Eds.), Vergangenheit in mündlicher Überlieferung (Colloquium Rauricum, vol. I), Stuttgart: 237-65.

J. Vansina (1985) Oral Tradition as History, Madison.

M. Weber (1968) Max Weber on Charisma and Institution Building, edited by S. N. Eisenstadt, Chicago and London.

S. West (1999) "Sophocles' Antigone and Herodotus Book Three", in J. Griffin (ed.) Sophocles Revisited: Essays Presented to Sir Hugh Lloyd-Jones, Oxford: 109-135.

N. White (2002) Individual and Conflict in Greek Ethics, Oxford.

T. Whitmarsh (2004) Ancient Greek Literature, Cambridge and Malden. 


\section{Série}

\section{Documentos}

Imprensa da Universidade de Coimbra

Coimbra University Press

2011

- $\mathrm{U}$

C • 